\title{
Mycobacteria and Autophagy: Many Questions and Few Answers
}

\author{
Min Liang ${ }^{1 \#}$, Zeshan Habib" ${ }^{1 \#, ~ K a o r i ~ S a k a m o t o ², ~}$ \\ Xi Chen ${ }^{1,3 *}$ and Gang $\mathrm{CaO}^{1 *}$ \\ ${ }^{1}$ State-key Laboratory of Agricultural \\ Microbiology, Huazhong Agricultural University, \\ Wuhan, 430070 China \\ 2Department of Pathology, College of Veterinary \\ Medicine, University of Georgia, Athens, GA, \\ 30602 USA \\ ${ }^{3}$ College of Informatics, Huazhong Agricultural \\ University, Wuhan, 430070 China \\ *Corresponding authors: chenxi_419@163.com; \\ gcao@mail.hzau.edu.cn \\ \#These authors contributed equally to this work.
}

DOI: http://dx.doi.org/10.21775/cimb.021.063

\begin{abstract}
Tuberculosis (TB) is an ancient disease caused by Mycobacterium tuberculosis (Mtb). TB is one of the world's deadliest diseases, with one-third of infected individuals falling ill each year especially in many developing countries. Upon invading host cells, such as macrophages, Mtb can replicate in infected cells by arresting phagosome maturation and then potentially escaping into the cytosol. Host cells have a mechanism to control intracellular $M$ tb by inducing autophagy, which is an elaborate cellular process to target intracellular pathogens for degradation in infected cells. However, some factors of $M t b$ are involved in defense against killing by autophagy. Thus, this review highlights the recent advances in the interactions between autophagy and $M$ tb.
\end{abstract}

\section{Introduction}

Tuberculosis (TB), an infectious bacterial disease, is caused by Mycobacterium tuberculosis (Mtb). It is transmitted mainly via droplets from people showing active respiratory disease to other people. Most infections with Mtb usually do not cause any symptoms; this is also known as latent tuberculosis, in which the person's immune system acts to "wall off" the bacteria (Saiga et al., 2011). Some latent infections can progress to active disease with severe symptoms, including chronic cough with bloodcontaining sputum, fever, and weight loss. Over 100 million people have died from tuberculosis in the past 100 years, and 9 million new cases were reported in 2014 (Zumla et al., 2015). It is estimated that 35 million will die from TB between 2000-2020 (Zumla et al., 2015).

During the early stage of infection, macrophages dominate the immune response, because macrophages are the major reservoir of $M t b$. The survival and multiplication of mycobacteria in macrophages and/or other host cells determine the outcomes of infection. Host cells have their own degradation systems to antagonize invading bacteria. Meanwhile, Mtb tries to avoid degradation by host cells. It is clear that Mtb can block phagosomal maturation and may escape into the cytosol for survival in macrophages. However, autophagy could target the cytosolic bacteria to lysosomes for degradation under certain conditions through unclear mechanisms. In light of the mysterious mechanism(s) of degradation of Mtb by the host during infection, we will focus on the cross-talk between autophagy and Mtb in this review.

\footnotetext{
Autophagy

Autophagy is a highly-conserved process that serves to deliver proteins or whole organelles to lysosomes for degradation. Three major forms, macroautophagy, microautophagy, and chaperone-mediated autophagy (CMA), have been identified. The form of autophagy discussed in this review refers to macroautophagy. Autophagy results in the engulfment of cytoplasmic proteins by a double membrane bounded structure, called the autophagosome, which is initiated from membrane sources, including: the endosome/Golgi system, endoplasmic reticulum-mitochondrial contact
} 
sites (Chan and Tang, 2013; Hamasaki et al., 2013), the plasma membrane (Ravikumar et al., 2010), and phospholipid precursors (Dupont et al., 2014). Autophagy-related genes (ATG) have been reported to be accountable for its execution, of which the ubiquitin-like conjugates, Atg12-Atg5 and LC3-phosphatidylethanolamine, are required for autophagosome formation. There are several regulators/stimulators of cell autophagy, including mammalian target of rapamycin (mTOR), presence of microbes (Tattoli et al., 2012), the TAB2/3-TAK1-IKK signaling axis (Criollo et al., 2011), events downstream of pattern recognition receptors (PRR) and immune cytokine activation (Lee et al., 2007), transcription factor EB (Settembre et al., 2011), and proteolytic systems via FOXO3a (Masiero et al., 2009). Meanwhile, autophagy activation is under the control of different promoters/inducers, such as the transcription factor, TFE3 (Martina et al., 2014), and drugs or nutritional supplements (Levine et al., 2015).
Through autophagy, the host cell combats intracellular pathogens by fusing autosomes with lysosomes to sustain homeostasis. Moreover, it is implicated that autophagy can modulate MHC Class I-mediated antigen cross-presentation (Oliveira and van Hall, 2015). When autophagy is impaired, it may contribute to the pathogenesis of some pulmonary diseases (Ryter and Choi, 2015).

\section{Restriction of intracellular Mtb replication by autophagy}

Mtb survives in infected host cells by blocking phagosome maturation or escaping from phagosomes to the cytosol; this is attributed to the failure of bacilli to undergo delivery into lysosomes (Figure 1). The purpose of this review is not to provide a comprehensive summary of phagosomal maturation arrest strategies used by $M t b$, as there are already excellent reviews covering this subject (Simeone et al., 2015; Welin and Lerm, 2012). Instead, this article will

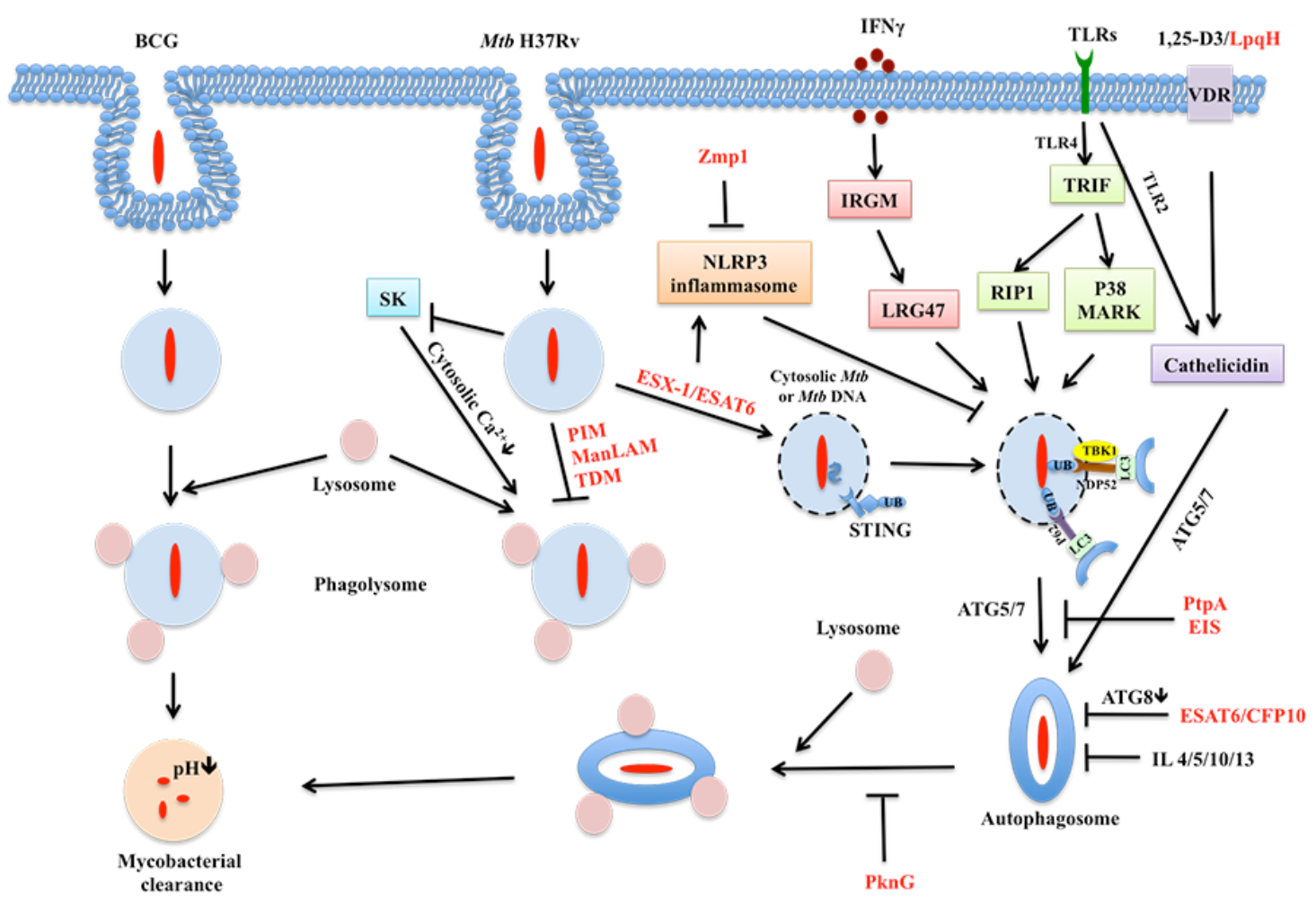

Figure 1. Interaction of Mtb with autophagy in host cells. 
focus exclusively on the killing mechanisms of autophagy and defense mechanisms against it used by Mtb.

Autophagy has been found to target intracellular mycobacteria to lysosomes for degradation, and several components are involved in this process. Human guanosine triphosphatases (GTPase) play pivotal roles in the elimination of intracellular $M t b$ by inducing autophagy and generating the autolysosome in macrophages (Singh et al., 2006). These GTPases regulate vesicular trafficking and protein complex assembly on Mtb-containing autophagic vacuoles in macrophages. Mtb infection is associated with polymorphisms in immunityrelated GTPase 1 (IRGM1), IFN-y, IFN-y receptor, TLR8, Vitamin D3 (VDR), and ATP receptor (P2X7R) (Jo, 2013; Saiga et al., 2011; Songane et al., 2012). The aggregation of IFN-Y with GTPase IRG-47 leads to reduced Mtb infection in macrophages of mice compared to IRG-47-/- mice (MacMicking et al., 2003). Initiating autophagy by IFN-y could efficiently suppress intracellular survival of $M t b$, along with colocalizing Mtb and Beclin-1, which boosts mycobacterial phagosome maturation in macrophages (Gutierrez et al., 2004).

Ubiquitin-derived peptides from Mtb-infected, macrophage lysosomes play a role in antimicrobial effects in host cells (Alonso et al., 2007). Mtb DNA can function as a signal to activate autophagy through the activation of the TBK1 and STING-dependent (stimulator of IFN genes) cytosolic pathways, which flag the bacteria with ubiquitin. TBK1 phosphorylates the autophagic receptor p62 (Pilli et al., 2012), while STING recognizes cyclic GMP-AMP (cGAMP) (Wu et al., 2013) generated by the host DNAreceptor cGAMP synthase, which finally activates the type I IFN pathway via TBK1 signaling (Sun et al., 2013). The ubiquitinautophagy receptors, p62 and NDP52, recognize the ubiquitin-labelled $M t b$ and transfer them to the autophagosome. STING-/- macrophages were highly susceptible to infection (Ishikawa et al., 2009). In addition, genetic polymorphisms in regulating ubiquitin ligase (PARK2) are associated with increased susceptibility to mycobacterial infections in humans. Ubiquitin aggregates in liver cells, and autophagosome formation is impaired in Atg7 $7^{-1-}$ mice (Komatsu et al., 2005). Knockout of Atg7 also increased the expression of scavenger receptors on $\operatorname{Atg} 7^{-/-}$ macrophages, which are more susceptible to $M t b$ infection and intracellular growth (Bonilla et al., 2013). Due to the degradation of mutant $\alpha 1-$ antitrypsin $Z$ ( $\alpha 1-A T Z$ ) protein by the ubiquitinproteasome system, autophagosomes accumulation in $\mathrm{Atg}^{-/-}$cell after transfection with a plasmid expressing a1-ATZ (Kamimoto et al., 2006), suggesting that the ubiquitin system could regulate $M$ tb in the autophagosome. Knockout of Atg5 in the myeloid lineage also causes the increase of bacillary burden but simultaneously increases damaging inflammation in mice (Castillo et al., 2012). Ubiquitin-derived peptides eradicate $M$ tb after multivesicular body trafficking of ubiquitin to the lysosome (Purdy and Russell, 2007a, b). Moreover, rapamycin (RAP) can enhance autophagy by improving presentation of Mtb antigen through antigen-presenting cells (macrophages and the dendritic cells) and strengthen the ability of dendritic cells to prime $T$ cells (Jagannath et al., 2009). It has also been reported that inhaled RAP induces autophagy in lung macrophages in situ, with substantial decreases in lung burden of Mtb (Gupta et al., 2016). Further, Nordihydroguaiaretic acid (NDGA) and $\alpha$-mangostin eradicate intracellular bacteria by inducing autophagy in human cells (Guzman-Beltran et al., 2016).

Stimulating $M t b$-infected cells with different Tolllike receptor (TLR) agonists can decrease the survival of Mtb. TLR2 binds with TLR1 or TLR6 to form heterodimers, which is critical for recognition of $M t b$ glycolipids (Kleinnijenhuis et al., 2011). Furthermore, TLR4, TLR9, and possibly TLR8 can also recognize $M t b$ (Kleinnijenhuis et al., 2011). In addition, TLR2/1 activation could increase the expression of the vitamin $\mathrm{D}$ receptor to reduce the viability of $M t b$ in monocytes and macrophages, since engagement of TLR2/1 and CD14 by the mycobacterial lipoprotein $\mathrm{LpqH}$ could activate autophagy by vitamin D signaling activation (Liu et al., 2006; Shin et al., 2010b). Calcitriol is produced by macrophages treated with calcidiol (25-hyfroxy vitamin D3) through TLR signaling, IFN- $y$, and other physiologic stimuli. Low levels of calcidiol and calcitriol in the serum are associated with susceptibility to tuberculosis (Fabri et al., 2011). During the killing of Mtb by Vitamin D3, cathelicidin is necessary in mediating autophagy by activation of BECN1 and Atg5 (Yuk et al., 2009). Moreover, the combination of IFN- $\gamma$ and vitamin $D$ triggers autophagic eradication of $M t b$ in human 
macrophages (Nnoaham and Clarke, 2008), but not in murine model (Harris et al., 2007).

In human monocytes/macrophages, cell autophagy induced by ATP could trigger lysosome fusion to kill intracellular $M t b$, which is dependent on $\mathrm{Ca}^{2+}$ and the $\mathrm{P}_{2} \mathrm{X}_{7}$ receptor (Biswas et al., 2008). Electron microscopy imaging of ATP-treated, BCG-infected monocytes-derived macrophages (MDMs) revealed the presence of the bacteria within autophagosomes characterized by doublemembrane, indicating autophagy associated with mycobacterial killing (Biswas et al., 2008).

Non-coding RNAs are also involved in autophagy. Long non-coding RNAs, such as MEG3, were found to be linked with $\mathrm{mTOR}$ and PI3K-AKT signaling in regulating autophagy of host cells during infection with the vaccine strain, M. bovis Bacille Calmette-Guérin (BCG). IFN-Yinduced autophagy in infected macrophages resulted in sustained MEG3 down-regulation, and knockdown of MEG3 in macrophages lead to induction of autophagy and enhanced eradication of intracellular BCG (Pawar et al., 2016). MiR-155, the most highly upregulated miRNA in Mtb-infected bone marrow-derived macrophages (BMDMs), is essential for $M$ tb survival and simultaneously destructive for the innate immune response. It is of interest that BCG could induce miR-155 to trigger the apoptosis of infected macrophages, which is necessary for strong protective immunity in the host. With deletion of miR-155, the apoptosis of infected macrophages was largely compromised (Ghorpade et al., 2012; Kumar et al., 2012).

\section{Mycobacteria can block autophagosome maturation to create a replicate niche}

Mycobacteria could interfere the defense of host cells through many factors (Table 1). Mtb virulent strains impair autophagy at the level of autophagosome-lysosome fusion that is ESX-1dependent in dendritic cells (Romagnoli et al., 2012). The ability to inhibit autophagy was fully restored in recombinant $\mathrm{BCG}$ and Mtb $\mathrm{H} 37 \mathrm{Ra}$ strains expressing either ESX-1 or the PhoP gene. After infecting host cells, Mtb can upregulate Th2-type cytokines, including interleukin-5 (IL-5), IL-10, and IL-13 (Freeman et al., 2006). Mtb can also stimulate peripheral blood mononuclear cells (PBMC) to synthesize IL-4 and IL-13, which is a hallmark of Th2polarized immunity. In tuberculosis patients, sensitivity of cells to IFN-y is reduced to interfere with autophagosome formation (Condos et al., 2003). The cytokines of Th1 and Th2 responses exhibit antagonistic effects on the formation of the autophagosome (Harris et al., 2007; Harris et al., 2009); Th1-type cytokines induce the formation of the autophagosome, while Th2-type cytokines inhibit formation. Infection with Mtb inhibits the increase in cytosolic $\mathrm{Ca}^{2+}$ by restricting the activity of macrophage sphingosine kinase (SK), which results in the inhibition of phagosome maturation (Thompson et al., 2005; Yadav et al., 2006). Mtb can also secrete ESAT- 6 and CFP-10 protein to inhibit autophagosome formation and survive in macrophages by decreasing ATG8 protein (Zhang et al., 2012).

The Mtb enhanced intracellular survival (eis) gene overturns macrophage autophagy through the inhibition of reactive oxygen species (ROS) generation (Shin et al., 2010a). Eis possibly interacts with specific autophagy factors or affects upstream signaling regulators that interfere with fusion between phagosomal compartments containing Mtb and lysosomes. Deletion of the Mtb eis gene could boost accumulation of massive autophagic vacuoles and formation of autophagosomes after infecting macrophages (Shin et al., 2010a). The Mtb mannose-capped lipoarabinomannan (ManLAM) could reduce the accumulation of autophagosomes and suppress the level of LC3 in phagosomal membranes in the RAW264.7 cell line (Shui et al., 2011). Further, Eis was reported to inhibit macrophage autophagy in the phorbol myristate acetate (PMA)-treated, human, THP-1 cell line and in murine macrophages through the up-regulation of IL-10 due to an increase in acetylation of histone $\mathrm{H} 3$ by the activation of the $\mathrm{PI3K} / \mathrm{Akt} / \mathrm{mTOR} / \mathrm{p} 70 \mathrm{~S} 6 \mathrm{~K}$ pathway (Duan et al., 2016).

IL-1 $\beta$ also plays an important role in macrophages by eradicating Mtb in host cells (Mayer-Barber et al., 2011). Deficiency of autophagosome forming-related protein could elevate endotoxin-induced IL- $1 \beta$ levels (Saitoh et al., 2008). On the contrary, induction of autophagy inhibits IL- $1 \beta$ secretion by degradation of pro-IL-1 $\beta$ (Harris et al., 2011). IL-1 receptor-deficient mice are more susceptible to $M$ tb infecton (Fremond et al., 2007). Mtbinfected, IL-1 $\beta^{-/-}$mice showed increased mortality and bacterial burden by a mechanism 


\begin{tabular}{|c|c|c|}
\hline Factors & Functions & References \\
\hline Vitamin D3 & $\begin{array}{l}\text { Trigger the formation of autophagosomes and } \\
\text { autophagolysosomes to eliminate } M t b \text { via cathelicidin }\end{array}$ & Yuk et al., 2009 \\
\hline $\begin{array}{l}\text { Ubiquitin derived } \\
\text { Peptide }\end{array}$ & Contribute to kill $M t b$ in the autophagolysosome & Alonso et al., 2007 \\
\hline mTOR & Lipid component of Mycobacteria induce mTOR activity & Zullo et al., 2012 \\
\hline INF- $\gamma$ & Induce autophagy to eliminate $M t b$ & $\begin{array}{l}\text { Songane et al., } 2012 \text {; } \\
\text { Condos et al., } 2003\end{array}$ \\
\hline IL-1 $\beta$ & $\begin{array}{l}\text { Induced by } M t b \text { and inhibition } M t b \text { by Vitamin D3 need IL-1 } \beta \\
\text { receptor } 1\end{array}$ & $\begin{array}{l}\text { Mayer-Barber et al., } \\
\text { 2011; Kleinnijenhuis et } \\
\text { al., } 2011\end{array}$ \\
\hline Rab GTPase & $\begin{array}{l}\text { Mtb recruits GTPase on its phagosome and prevent } \\
\text { phagolysosome biogenesis }\end{array}$ & $\begin{array}{l}\text { Lopez de Armentia et } \\
\text { al., } 2016\end{array}$ \\
\hline ATP & Trigger autophagy to kill intracellular $M t b$ & Biswas et al., 2008 \\
\hline Rapamycin & $\begin{array}{l}\text { Improve autophagy by presenting more } M t b \text { antigen and } \\
\text { strengthen the ability of dendritic cells to prime } \mathrm{T} \text { cells }\end{array}$ & Jagannath et al., 2009 \\
\hline $\begin{array}{l}\text { T helper } 2 \text { cytokines } \\
(\mathrm{IL}-4,5,10,13)\end{array}$ & $\begin{array}{l}\text { Inhibit autophagic } M t b \text { phagolysosome maturation and limination } \\
\text { of } M t b \text { by autophagy }\end{array}$ & Harris J et al., 2007 \\
\hline Eis & $\begin{array}{l}\text { Eis-deletion } M t b \text { increased accumulation of massive autophagic } \\
\text { vacuoles and formation of autophagosomes }\end{array}$ & Shin, D.M et al., 2010 \\
\hline $\operatorname{miR}-155$ & $M t b$ infection upregulate miR-155 to modulate cell apoptosis & $\begin{array}{l}\text { Ghorpade et al., 2012; } \\
\text { Kumar et al., } 2012\end{array}$ \\
\hline $\operatorname{miR}-30 \mathrm{~A}$ & $\begin{array}{l}\text { Mtb infection upregulate miR-30A to escape from intracellular } \\
\text { elimination }\end{array}$ & Chen et al., 2015 \\
\hline MiR-33 & $\begin{array}{l}\text { Inhibition of miR-33 enhance killing } M t b \text { by upregulate } \\
\text { autophagy }\end{array}$ & Ouimet et al., 2016 \\
\hline $\begin{array}{l}\mathrm{Zn}^{2+} \\
\text { metalloprotease } \\
(\mathrm{Zmp} 1)\end{array}$ & $\begin{array}{l}\mathrm{Zmp} 1 \text { is required for } M t b \text { virulence and inhibition of host cell } \\
\text { inflammasome activation }\end{array}$ & Master et al., 2008 \\
\hline $\begin{array}{l}\text { Sphingosine kinase } \\
1 \text { (SK1) }\end{array}$ & $\begin{array}{l}\text { Activation of SK is inhibited by } M t b \text { and increase of SK activity } \\
\text { is associated with phagocytosis }\end{array}$ & $\begin{array}{l}\text { Thompson et al., } 2005 \text {; } \\
\text { Yadav et al., } 2006\end{array}$ \\
\hline $\mathrm{Bfl}-1 / \mathrm{Al}$ & Negtively regulate autophagy in $M t b$ infected host cells & Kathania et al., 2011 \\
\hline ESAT6/CFP-10 & $\begin{array}{l}\text { Inhibition of autophagosome formation and allow } M t b \text { to survive } \\
\text { in host cell }\end{array}$ & Zhang et al., 2012 \\
\hline PtpA & $\begin{array}{l}\text { Secreted by } M t b \text { and inhibit phagosome-lysosome fusion by } \\
\text { dephosphorylating host cell VPS33B to persistence } \\
\text { intracellularly. }\end{array}$ & Bach et al., 2008 \\
\hline $\mathrm{TAB} 2 / 3$ & $\begin{array}{l}\text { Interact with beclin } 1 \text { and inhibit autophagy, dissciate with beclin } \\
1 \text { induce autophagy }\end{array}$ & Criollo et al., 2011 \\
\hline PIM & Stimulate fusion between phagosomes and early endosomes & Vergne et al., 2004 \\
\hline ManLAM & Inhibit accumulation of autophagic vacuoles in host cell & Shui et al., 2011 \\
\hline
\end{tabular}


that does not require TLR signaling or caspase-1 (Mayer-Barber et al., 2010). The deficiency of Zmp1 $\left(\mathrm{Zn}^{2+}\right.$ metalloprotease $)$ in $\mathrm{Mtb}$ could attenuate $M t b$ virulence and induce IL-1 $\beta$ during Mtb infection (Master et al., 2008).

It has been reported that $M t b$ can upregulate miR-30A to escape intracellular elimination in macrophages (Chen et al., 2015). MiRNA downregulates Beclin and ATG5 expression, and inhibits autophagy (Zou et al., 2012). Exogenous and overexpression of miR-30A could prevent abolition of intracellular $M t b$ by inhibiting autophagy. Another study reported that Mtb regulates miR-155 through an ESAT6-dependent manner to overcome its elimination and promote infection in macrophages (Kumar et al., 2012). Mtb also induces miR-33 and its passenger strand to inhibit integrated pathways involved in autophagy and reprogram host lipid metabolism to enable intracellular survival (Ouimet et al., 2016). Mtb blocks the autophagic machinery by blocking phagosome maturation through secretion of the macromolecules, PtpA and SapM. PtpA is crucial for Mtb pathogenicity within the macrophage (Bach et al., 2008). Mtb also utilizes Rab GTPases, which regulate phagosomal maturation to escape autophagy (Lopez de Armentia et al., 2016). Rab GTPases interferes with late endosome/lysosome vesicular interactions, leading to arrested autophagy (Lopez de Armentia et al., 2016). Mtb H37Rv limits autophagy by upregulating the expression of host anti-autophagic factor, Bfl-1/ A1 (Kathania et al., 2011). Down-regulation of Bfl-1/A1 by siRNA prompted autophagy and suppressed bacterial growth, confirming the role of $\mathrm{Bfl}-1 / \mathrm{A} 1$ in helping bacteria to outmaneuver host defenses. Mtb products, like the PI3P phosphatase, SapM, glycosylated phosphatidylinositol-mimic, LAM, and phosphatidylinositol mannoside (PIM) were reported to suppress PI3K signaling to offset autophagy (Ramachandra et al., 2005).

\section{Conclusion}

Autophagy is an efficient way to clear intracellular pathogens, including $M t b$, in eukaryotic cells. Although autophagy-based therapies have clear potential as a Mtb treatment strategy, the knowledge of how autophagy kills $M$ tb in vivo is still far from complete. In addition, how Mtb escape elimination by autophagy is poorly understood. Several questions remain: (1) How does Mtb escape lysosomal delivery inside of infected host cells; (2) Which factors of Mtb are involved in escaping degradation by autophagy in infected cells; (3) Will therapies based on boosting host cell autophagy be able to eradicate $M t b$ infection?

\section{Acknowledgements}

We thank Dr. Jinxia Dai for her suggestions. This work was supported by the National Natural Science Foundation of China (Grant No. 31371106, 31421064) and the China Postdoctoral Science Foundation (Grant No. 2015M572171).

\section{Disclosure statement}

The authors do not have financial or commercial competing interests.

\section{References}

Alonso, S., Pethe, K., Russell, D.G., and Purdy, G.E. (2007). Lysosomal killing of Mycobacterium mediated by ubiquitin-derived peptides is enhanced by autophagy. Proc Natl Acad Sci U S A 104, 6031-6036.

Biswas, D., Qureshi, O.S., Lee, W.Y., Croudace, J.E., Mura, M., and Lammas, D.A. (2008). ATP-induced autophagy is associated with rapid killing of intracellular Mycobacteria within human monocytes/macrophages. BMC Immunol 9, 35.

Bonilla, D.L., Bhattacharya, A., Sha, Y., Xu, Y., Xiang, Q., Kan, A., Jagannath, C., Komatsu, M., and Eissa, N.T. (2013). Autophagy regulates phagocytosis by modulating the expression of scavenger receptors. Immunity 39, 537-547.

Castillo, E.F., Dekonenko, A., Arko-Mensah, J., Mandell, M.A., Dupont, N., Jiang, S., DelgadoVargas, M., Timmins, G.S., Bhattacharya, D., Yang, H., et al. (2012). Autophagy protects against active tuberculosis by suppressing bacterial burden and inflammation. Proc Natl Acad Sci U S A 109, E3168-3176.

Chan, S.N., and Tang, B.L. (2013). Location and membrane sources for autophagosome formation - from ER-mitochondria contact sites to Golgi-endosome-derived carriers. Mol Membr Biol 30, 394-402.

Chen, Z., Wang, T., Liu, Z., Zhang, G., Wang, J., Feng, S., and Liang, J. (2015). Inhibition of Autophagy by MiR-30A Induced by Mycobacteria tuberculosis as a Possible Mechanism of Immune Escape in Human Macrophages. Jpn J Infect Dis 68, 420-424.

Condos, R., Raju, B., Canova, A., Zhao, B.Y., Weiden, M., Rom, W.N., and Pine, R. (2003). 
Recombinant gamma interferon stimulates signal transduction and gene expression in alveolar macrophages in vitro and in tuberculosis patients. Infection and immunity 71, 2058-2064.

Criollo, A., Niso-Santano, M., Malik, S.A., Michaud, M., Morselli, E., Marino, G., Lachkar, S., Arkhipenko, A.V., Harper, F., Pierron, G., et al. (2011). Inhibition of autophagy by TAB2 and TAB3. EMBO J 30, 4908-4920.

Duan, L., Yi, M., Chen, J., Li, S., and Chen, W. (2016). Mycobacterium tuberculosis EIS gene inhibits macrophage autophagy through upregulation of $\mathrm{IL}-10$ by increasing the acetylation of histone $\mathrm{H} 3$. Biochemical and biophysical research communications 473 , 1229-1234.

Dupont, N., Chauhan, S., Arko-Mensah, J., Castillo, E.F., Masedunskas, A., Weigert, R., Robenek, H., Proikas-Cezanne, T., and Deretic, V. (2014). Neutral lipid stores and lipase PNPLA5 contribute to autophagosome biogenesis. Curr Biol 24, 609-620.

Fabri, M., Stenger, S., Shin, D.M., Yuk, J.M., Liu, P.T., Realegeno, S., Lee, H.M., Krutzik, S.R., Schenk, M., Sieling, P.A., et al. (2011). Vitamin $D$ is required for IFN-gamma-mediated antimicrobial activity of human macrophages. Sci Transl Med 3, 104ra102.

Freeman, S., Post, F.A., Bekker, L.G., Harbacheuski, R., Steyn, L.M., Ryffel, B., Connell, N.D., Kreiswirth, B.N., and Kaplan, G. (2006). Mycobacterium tuberculosis H37Ra and H37Rv differential growth and cytokine/ chemokine induction in murine macrophages in vitro. J Interferon Cytokine Res 26, 27-33.

Fremond, C.M., Togbe, D., Doz, E., Rose, S., Vasseur, V., Maillet, I., Jacobs, M., Ryffel, B., and Quesniaux, V.F. (2007). IL-1 receptormediated signal is an essential component of MyD88-dependent innate response to Mycobacterium tuberculosis infection. Journal of immunology 179, 1178-1189.

Ghorpade, D.S., Leyland, R., KurowskaStolarska, M., Patil, S.A., and Balaji, K.N. (2012). MicroRNA-155 is required for Mycobacterium bovis BCG-mediated apoptosis of macrophages. Mol Cell Biol 32, 2239-2253.

Gupta, A., Sharma, D., Meena, J., Pandya, S., Sachan, M., Kumar, S., Singh, K., Mitra, K., Sharma, S., Panda, A.K., et al. (2016). Preparation and preclinical evaluation of inhalable particles containing rapamycin and anti-tuberculosis agents for induction of autophagy. Pharm Res.

Gutierrez, M.G., Master, S.S., Singh, S.B., Taylor, G.A., Colombo, M.I., and Deretic, V. (2004). Autophagy is a defense mechanism inhibiting BCG and Mycobacterium tuberculosis survival in infected macrophages. Cell 119, 753-766.

Guzman-Beltran, S., Rubio-Badillo, M.A., Juarez, E., Hernandez-Sanchez, F., and Torres, M. (2016). Nordihydroguaiaretic acid (NDGA) and alpha-mangostin inhibit the growth of Mycobacterium tuberculosis by inducing autophagy. Int Immunopharmacol 31, 149-157.

Hamasaki, M., Furuta, N., Matsuda, A., Nezu, A., Yamamoto, A., Fujita, N., Oomori, H., Noda, T., Haraguchi, T., Hiraoka, Y., et al. (2013). Autophagosomes form at ER-mitochondria contact sites. Nature 495, 389-393.

Harris, J., De Haro, S.A., Master, S.S., Keane, J., Roberts, E.A., Delgado, M., and Deretic, V. (2007). T helper 2 cytokines inhibit autophagic control of intracellular Mycobacterium tuberculosis. Immunity 27, 505-517.

Harris, J., Hartman, M., Roche, C., Zeng, S.G., O'Shea, A., Sharp, F.A., Lambe, E.M., Creagh, E.M., Golenbock, D.T., Tschopp, J., et al. (2011). Autophagy controls IL-1beta secretion by targeting pro-IL-1beta for degradation. The Journal of biological chemistry 286, 9587-9597.

Harris, J., Master, S.S., De Haro, S.A., Delgado, M., Roberts, E.A., Hope, J.C., Keane, J., and Deretic, V. (2009). Th1-Th2 polarisation and autophagy in the control of intracellular Mycobacteria by macrophages. Vet Immunol Immunopathol 128, 37-43.

Ishikawa, H., Ma, Z., and Barber, G.N. (2009). STING regulates intracellular DNA-mediated, type I interferon-dependent innate immunity. Nature 461, 788-792.

Jagannath, C., Lindsey, D.R., Dhandayuthapani, S., Xu, Y., Hunter, R.L., Jr., and Eissa, N.T. (2009). Autophagy enhances the efficacy of BCG vaccine by increasing peptide presentation in mouse dendritic cells. Nat Med 15, 267-276.

Jo, E.K. (2013). Autophagy as an innate defense against Mycobacteria. Pathog Dis 67, 108-118.

Kamimoto, T., Shoji, S., Hidvegi, T., Mizushima, N., Umebayashi, K., Perlmutter, D.H., and Yoshimori, T. (2006). Intracellular inclusions containing mutant alpha1-antitrypsin $\mathrm{Z}$ are propagated in the absence of autophagic 
activity. The Journal of biological chemistry 281, 4467-4476.

Kathania, M., Raje, C.I., Raje, M., Dutta, R.K., and Majumdar, S. (2011). Bfl-1/A1 acts as a negative regulator of autophagy in Mycobacteria infected macrophages. Int $\mathrm{J}$ Biochem Cell Biol 43, 573-585.

Kleinnijenhuis, J., Oosting, M., Joosten, L.A., Netea, M.G., and Van Crevel, R. (2011). Innate immune recognition of Mycobacterium tuberculosis. Clin Dev Immunol 2011, 405310.

Komatsu, M., Waguri, S., Ueno, T., Iwata, J., Murata, S., Tanida, I., Ezaki, J., Mizushima, N., Ohsumi, Y., Uchiyama, Y., et al. (2005). Impairment of starvation-induced and constitutive autophagy in Atg7-deficient mice. The Journal of cell biology 169, 425-434.

Kumar, R., Halder, P., Sahu, S.K., Kumar, M., Kumari, M., Jana, K., Ghosh, Z., Sharma, P., Kundu, M., and Basu, J. (2012). Identification of a novel role of ESAT-6-dependent miR-155 induction during infection of macrophages with Mycobacterium tuberculosis. Cellular microbiology 14, 1620-1631.

Lee, H.K., Lund, J.M., Ramanathan, B., Mizushima, N., and Iwasaki, A. (2007). Autophagy-dependent viral recognition by plasmacytoid dendritic cells. Science 315, 1398-1401.

Levine, B., Packer, M., and Codogno, P. (2015). Development of autophagy inducers in clinical medicine. J Clin Invest 125, 14-24.

Liu, P.T., Stenger, S., Li, H., Wenzel, L., Tan, B.H., Krutzik, S.R., Ochoa, M.T., Schauber, J., Wu, K., Meinken, C., et al. (2006). Toll-like receptor triggering of a vitamin D-mediated human antimicrobial response. Science 311, 1770-1773.

Lopez de Armentia, M.M., Amaya, C., and Colombo, M.I. (2016). Rab GTPases and the Autophagy pathway: bacterial targets for a suitable biogenesis and trafficking of their own vacuoles. Cells 5 .

MacMicking, J.D., Taylor, G.A., and McKinney, J.D. (2003). Immune control of tuberculosis by IFN-gamma-inducible LRG-47. Science 302, 654-659.

Martina, J.A., Diab, H.I., Lishu, L., Jeong, A.L., Patange, S., Raben, N., and Puertollano, R. (2014). The nutrient-responsive transcription factor TFE3 promotes autophagy, lysosomal biogenesis, and clearance of cellular debris. Sci Signal 7, ra9.

Masiero, E., Agatea, L., Mammucari, C., Blaauw, B., Loro, E., Komatsu, M., Metzger, D.,
Reggiani, C., Schiaffino, S., and Sandri, M. (2009). Autophagy is required to maintain muscle mass. Cell Metab 10, 507-515.

Master, S.S., Rampini, S.K., Davis, A.S., Keller, C., Ehlers, S., Springer, B., Timmins, G.S., Sander, P., and Deretic, V. (2008). Mycobacterium tuberculosis prevents inflammasome activation. Cell Host Microbe 3, 224-232.

Mayer-Barber, K.D., Andrade, B.B., Barber, D.L., Hieny, S., Feng, C.G., Caspar, P., Oland, S., Gordon, S., and Sher, A. (2011). Innate and adaptive interferons suppress IL-1alpha and IL-1beta production by distinct pulmonary myeloid subsets during Mycobacterium tuberculosis infection. Immunity 35 , 1023-1034.

Mayer-Barber, K.D., Barber, D.L., Shenderov, K., White, S.D., Wilson, M.S., Cheever, A., Kugler, D., Hieny, S., Caspar, P., Nunez, G., et al. (2010). Caspase-1 independent IL-1beta production is critical for host resistance to Mycobacterium tuberculosis and does not require TLR signaling in vivo. Journal of immunology 184, 3326-3330.

Nnoaham, K.E., and Clarke, A. (2008). Low serum vitamin $D$ levels and tuberculosis: a systematic review and meta-analysis. Int $\mathrm{J}$ Epidemiol 37, 113-119.

Oliveira, C.C., and van Hall, T. (2015). Alternative Antigen Processing for MHC Class I: Multiple Roads Lead to Rome. Front Immunol 6, 298.

Ouimet, M., Koster, S., Sakowski, E., Ramkhelawon, B., van Solingen, C., Oldebeken, S., Karunakaran, D., PortalCelhay, C., Sheedy, F.J., Ray, T.D., et al. (2016). Mycobacterium tuberculosis induces the miR-33 locus to reprogram autophagy and host lipid metabolism. Nat Immunol.

Pawar, K., Hanisch, C., Palma Vera, S.E., Einspanier, R., and Sharbati, S. (2016). Down regulated IncRNA MEG3 eliminates Mycobacteria in macrophages via autophagy. Sci Rep 6, 19416.

Pilli, M., Arko-Mensah, J., Ponpuak, M., Roberts, E., Master, S., Mandell, M.A., Dupont, N., Ornatowski, W., Jiang, S., Bradfute, S.B., et al. (2012). TBK-1 promotes autophagy-mediated antimicrobial defense by controlling autophagosome maturation. Immunity 37 , 223-234.

Purdy, G.E., and Russell, D.G. (2007a). Lysosomal ubiquitin and the demise of 
Mycobacterium tuberculosis. Cellular microbiology 9, 2768-2774.

Purdy, G.E., and Russell, D.G. (2007b). Ubiquitin trafficking to the lysosome: keeping the house tidy and getting rid of unwanted guests. Autophagy 3, 399-401.

Ramachandra, L., Smialek, J.L., Shank, S.S., Convery, M., Boom, W.H., and Harding, C.V. (2005). Phagosomal processing of Mycobacterium tuberculosis antigen $85 \mathrm{~B}$ is modulated independently of mycobacterial viability and phagosome maturation. Infection and immunity $73,1097-1105$.

Ravikumar, B., Moreau, K., Jahreiss, L., Puri, C., and Rubinsztein, D.C. (2010). Plasma membrane contributes to the formation of preautophagosomal structures. Nat Cell Biol 12, 747-757.

Romagnoli, A., Etna, M.P., Giacomini, E., Pardini, M., Remoli, M.E., Corazzari, M., Falasca, L., Goletti, D., Gafa, V., Simeone, R., et al. (2012). ESX-1 dependent impairment of autophagic flux by Mycobacterium tuberculosis in human dendritic cells. Autophagy 8 , 1357-1370.

Ryter, S.W., and Choi, A.M. (2015). Autophagy in lung disease pathogenesis and therapeutics. Redox Biol 4, 215-225.

Saiga, H., Shimada, Y., and Takeda, K. (2011). Innate immune effectors in mycobacterial infection. Clin Dev Immunol 2011, 347594.

Saitoh, T., Fujita, N., Jang, M.H., Uematsu, S., Yang, B.G., Satoh, T., Omori, H., Noda, T., Yamamoto, N., Komatsu, M., et al. (2008). Loss of the autophagy protein Atg16L 1 enhances endotoxin-induced IL-1beta production. Nature 456, 264-268.

Settembre, C., Di Malta, C., Polito, V.A., Garcia Arencibia, M., Vetrini, F., Erdin, S., Erdin, S.U., Huynh, T., Medina, D., Colella, P., et al. (2011). TFEB links autophagy to lysosomal biogenesis. Science 332, 1429-1433.

Shin, D.M., Jeon, B.Y., Lee, H.M., Jin, H.S., Yuk, J.M., Song, C.H., Lee, S.H., Lee, Z.W., Cho, S.N., Kim, J.M., et al. (2010a). Mycobacterium tuberculosis eis regulates autophagy, inflammation, and cell death through redoxdependent signaling. PLoS Pathog 6, e1001230.

Shin, D.M., Yuk, J.M., Lee, H.M., Lee, S.H., Son, J.W., Harding, C.V., Kim, J.M., Modlin, R.L., and Jo, E.K. (2010b). Mycobacterial lipoprotein activates autophagy via TLR2/1/ CD14 and a functional vitamin D receptor signalling. Cellular microbiology 12 , 1648-1665.

Shui, W., Petzold, C.J., Redding, A., Liu, J., Pitcher, A., Sheu, L., Hsieh, T.Y., Keasling, J.D., and Bertozzi, C.R. (2011). Organelle membrane proteomics reveals differential influence of mycobacterial lipoglycans on macrophage phagosome maturation and autophagosome accumulation. Journal of proteome research 10, 339-348.

Simeone, R., Sayes, F., Song, O., Groschel, M.I., Brodin, P., Brosch, R., and Majlessi, L. (2015). Cytosolic access of Mycobacterium tuberculosis: critical impact of phagosomal acidification control and demonstration of occurrence in vivo. PLoS Pathog 11, e1004650.

Singh, S.B., Davis, A.S., Taylor, G.A., and Deretic, V. (2006). Human IRGM induces autophagy to eliminate intracellular mycobacteria. Science 313, 1438-1441.

Songane, M., Kleinnijenhuis, J., Netea, M.G., and van Crevel, R. (2012). The role of autophagy in host defence against Mycobacterium tuberculosis infection. Tuberculosis (Edinb) 92, 388-396.

Sun, L., Wu, J., Du, F., Chen, X., and Chen, Z.J. (2013). Cyclic GMP-AMP synthase is a cytosolic DNA sensor that activates the type I interferon pathway. Science 339, 786-791.

Tattoli, I., Sorbara, M.T., Vuckovic, D., Ling, A., Soares, F., Carneiro, L.A., Yang, C., Emili, A., Philpott, D.J., and Girardin, S.E. (2012). Amino acid starvation induced by invasive bacterial pathogens triggers an innate host defense program. Cell Host Microbe 11, 563-575.

Thompson, C.R., lyer, S.S., Melrose, N., VanOosten, R., Johnson, K., Pitson, S.M., Obeid, L.M., and Kusner, D.J. (2005). Sphingosine kinase 1 (SK1) is recruited to nascent phagosomes in human macrophages: inhibition of SK1 translocation by Mycobacterium tuberculosis. Journal of immunology 174, 3551-3561.

Welin, A., and Lerm, M. (2012). Inside or outside the phagosome? The controversy of the intracellular localization of Mycobacterium tuberculosis. Tuberculosis (Edinb) 92, 113-120.

Wu, J., Sun, L., Chen, X., Du, F., Shi, H., Chen, C., and Chen, Z.J. (2013). Cyclic GMP-AMP is an endogenous second messenger in innate immune signaling by cytosolic DNA. Science 339, 826-830. 
Yadav, M., Clark, L., and Schorey, J.S. (2006). Macrophage's proinflammatory response to a mycobacterial infection is dependent on sphingosine kinase-mediated activation of phosphatidylinositol phospholipase $\mathrm{C}$, protein kinase C, ERK1/2, and phosphatidylinositol 3kinase. Journal of immunology 176, 54945503.

Yuk, J.M., Shin, D.M., Lee, H.M., Yang, C.S., Jin, H.S., Kim, K.K., Lee, Z.W., Lee, S.H., Kim, J.M., and Jo, E.K. (2009). Vitamin D3 induces autophagy in human monocytes/macrophages via cathelicidin. Cell Host Microbe 6, 231-243.

Zhang, L., Zhang, H., Zhao, Y., Mao, F., Wu, J., Bai, B., Xu, Z., Jiang, Y., and Shi, C. (2012).
Effects of Mycobacterium tuberculosis ESAT-6/ CFP-10 fusion protein on the autophagy function of mouse macrophages. DNA Cell Biol 31, 171-179.

Zou, Z., Wu, L., Ding, H., Wang, Y., Zhang, Y., Chen, X., Chen, X., Zhang, C.Y., Zhang, Q., and Zen, K. (2012). MicroRNA-30a sensitizes tumor cells to cis-platinum via suppressing beclin 1-mediated autophagy. The Journal of biological chemistry 287, 4148-4156.

Zumla, A., George, A., Sharma, V., Herbert, R.H., Baroness Masham of, I., Oxley, A., and Oliver, M. (2015). The WHO 2014 global tuberculosis report--further to go. Lancet Glob Health 3, e10-12. 


\section{Microbiology / Molecular Biology}

Caister Academic Press is a leading academic publisher of advanced texts in microbiology, molecular biology and medical research. Full details of all our publications at caister.com

- Cyanobacteria: Omics and Manipulation Edited by: DA Los (2017) www.caister.com/cyano3

- Brain-eating Amoebae: Biology and Pathogenesis of Naegleria fowleri

Author: R Siddiqui, IKM Ali, JR Cope, et al. (2016)

"explains the current knowledge and research" (ProtoView) www.caister.com/naegleria

- Foot and Mouth Disease Virus: Current Research and Emerging Trends

Edited by: F Sobrino, E Domingo (2017)

www.caister.com/fmdv

- Staphylococcus: Genetics and Physiology

Edited by: GA Somerville (2016)

www.caister.com/staph2

- Chloroplasts: Current Research and Future Trends Edited by: H Kirchhoff (2016)

www.caister.com/chloroplasts

- Microbial Biodegradation: From Omics to Function and Application

Edited by: J Długoński (2016)

www.caister.com/biodegradation

- Influenza: Current Research

Edited by: Q Wang, YJ Tao (2016)

www.caister.com/flu3

- MALDI-TOF Mass Spectrometry in Microbiology Edited by: M Kostrzewa, S Schubert (2016)

www.caister.com/malditof

- Aspergillus and Penicillium in the Post-genomic Era Edited by: RP Vries, IB Gelber, MR Andersen (2016)

"new and well-presented book" (IMA Fungus)

www.caister.com/aspergillus2

- The Bacteriocins: Current Knowledge and Future

Prospects

Edited by: RL Dorit, SM Roy, MA Riley (2016)

www.caister.com/bacteriocins

- Omics in Plant Disease Resistance

Edited by: V Bhadauria (2016)

"essential reading ... highly recommended" (Biotechnol. Agron.

Soc. Environ.)

www.caister.com/opdr

- Acidophiles: Life in Extremely Acidic Environments

Edited by: R Quatrini, DB Johnson (2016)

"Contributors from a wide range of biological and environmental sciences" (ProtoView)

www.caister.com/acidophiles
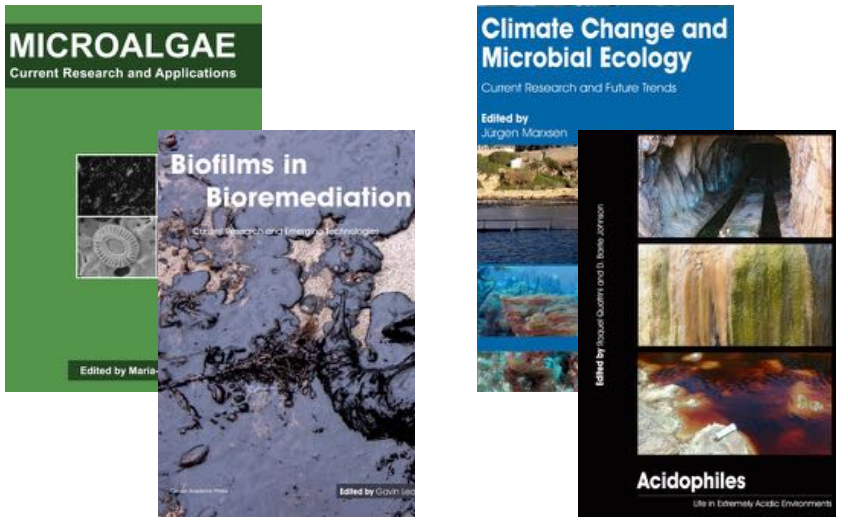
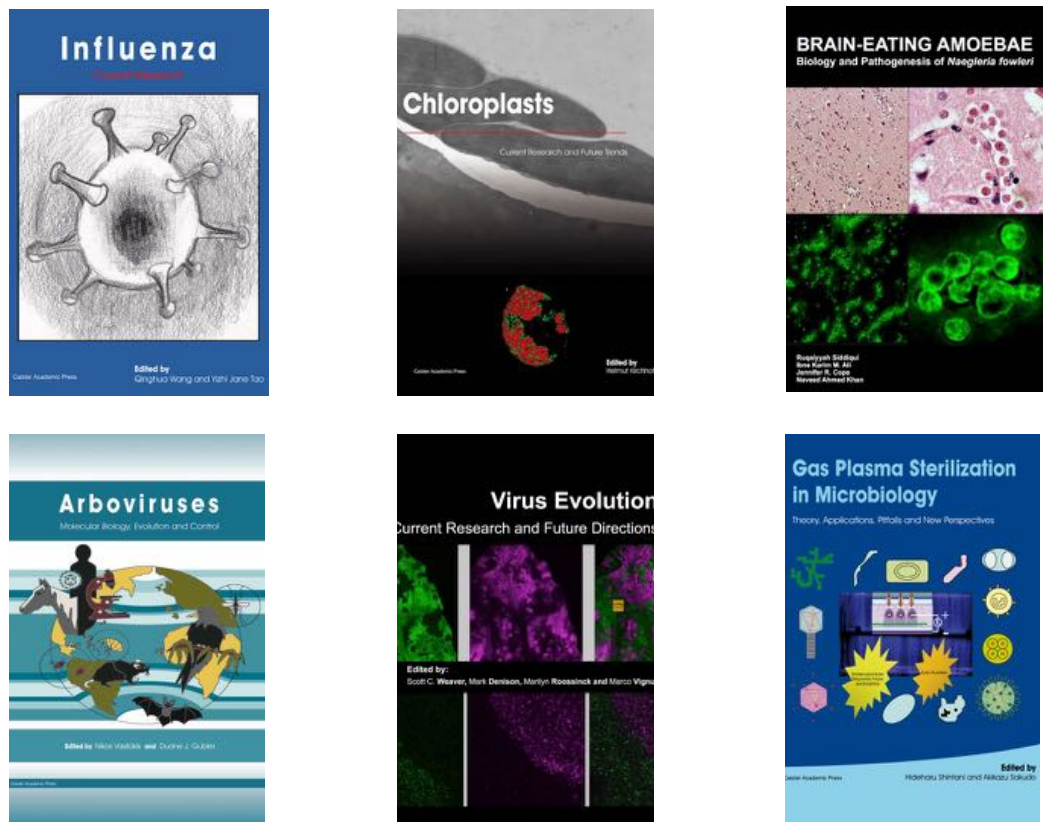

- Climate Change and Microbial Ecology: Current Research and Future Trends

Edited by: J Marxsen (2016)

"impressive" (ASM: Small Things Considered); "written at a high scientific level" (BioSpektrum)

www.caister.com/climate

- Biofilms in Bioremediation: Current Research and Emerging Technologies

Edited by: G Lear (2016)

"describes explicitly the role of biofilms in bioremediation" (Biospektrum); indispensable ... recommended (Biotechnol. Agron. Soc. Environ.) www.caister.com/biorem

- Microalgae: Current Research and Applications

Edited by: MN Tsaloglou (2016)

www.caister.com/microalgae

- Gas Plasma Sterilization in Microbiology: Theory, Applications, Pitfalls and New Perspectives

Edited by: H Shintani, A Sakudo (2016)

"a nice state of the art compilation" (Doodys)

www.caister.com/gasplasma

- Virus Evolution: Current Research and Future Directions Edited by: SC Weaver, M Denison, M Roossinck, et al. (2016) "highly informative ... a pleasure to read" (Microbiol. Today) www.caister.com/virusevol

- Arboviruses: Molecular Biology, Evolution and Control Edited by: N Vasilakis, DJ Gubler (2016)

"a thorough and compelling review ... an outstanding book ... highly recommended" (Am. J. Trop. Med. Hyg.) www.caister.com/arbo

- Shigella: Molecular and Cellular Biology

Edited by: WD Picking, WL Picking (2016)

www.caister.com/shigella

- Aquatic Biofilms: Ecology, Water Quality and Wastewater Treatment

Edited by: AM Romaní, H Guasch, MD Balaguer (2016)

"essential reference book" (Biotechnol. Agron. Soc. Environ.)

www.caister.com/aquaticbiofilms

- Alphaviruses: Current Biology

Edited by: S Mahalingam, L Herrero, B Herring (2016)

"up-to-date review of the field" (Aus. Vet. J.)

www.caister.com/alpha 